\title{
Postmortem molecular diagnosis of sickle $\beta$ thalassaemia
}

\author{
F Kutlar, D Mirmow, M Glendenning, L Holley, A Kutlar
}

J Clin Pathol 2005;58:548-549. doi: 10.1136/icp.2004.018127

This report describes a case in which the diagnosis of sickle cell disease (SCD) was established after death. The diagnosis of sickle cell syndrome was made in a 68 year old black patient who was found to have sickled red blood cells in many organs at necropsy although the disease had not been diagnosed during her lifetime. DNA was isolated from a peripheral blood smear obtained on the day of the patient's death. The $\beta$ globin gene was polymerase chain reaction amplified and sequenced, revealing that the patient had S- $\beta^{+}$ thalassaemia. This study shows that blood smears are a suitable source for retrospective DNA analysis studies. This case illustrates that relatively "mild" forms of SCD can be overlooked, despite symptomatology suggestive of a sickle syndrome, and demonstrates the feasibility of the postmortem molecular diagnosis of haemoglobinopathies in such cases.

$\mathrm{S}$ ickle cell disease (SCD) is commonly diagnosed at birth through newborn screening programmes. Some patients with milder forms of SCD (SC and S- $\beta^{+}$thalassaemia) are diagnosed in adulthood, either fortuitously or when they present with various complications. The molecular analysis of genomic DNA is widely used for the diagnosis of haemoglobinopathies. Although freshly collected blood is used for molecular diagnostic studies, this is not applicable for postmortem diagnosis. There have been reports on the use of DNA obtained posthumously from bone marrow slides and from archaeological remains for the molecular diagnosis of haemoglobinopathies. ${ }^{12}$ The amplification of DNA from glass slides by polymerase chain reaction (PCR) methods provides a valuable tool for retrospective studies..$^{3-5}$

\section{CASE REPORT}

A 68 year old black woman presented to a local hospital with severe chest, arm, and back pains. She was transferred to a regional medical centre in South Carolina with a diagnosis of possible aortic aneurysm. This was ruled out by a computed tomography scan, which showed cervical spinal stenosis and stenotic changes in the lumbar spine. She died of respiratory failure on day 5. Laboratory findings showed renal failure, raised liver function tests, and extremely high lactate dehydrogenase. A peripheral blood smear showed a large number of nucleated red blood cells. Her past medical history included hypertension, diabetes, hip replacement, and cholecystectomy. Major macroscopic findings at necropsy included splenic infarction. Microscopic examination revealed the presence of sickled red blood cells in many organs. Fat emboli were seen diffusely in small vessels in the lungs, heart, kidney, and brain. It was concluded that the patient died from systemic fat embolisation, probably originating from bone marrow infarction.

\section{MATERIAL AND METHODS}

A Wright's stained peripheral blood smear obtained on the day of the patient's death was submitted to the DNA laboratory of the sickle cell center at the Medical College of Georgia (MCG), USA. The smear was placed in xylene at room temperature for six days. On day 7 , the cover glass was removed, the smear was rinsed with deionised water, and then dried at room temperature. Blood was collected from the slide with $250 \mu \mathrm{l}$ of digestion solution and transferred into an Eppendorf tube. DNA was isolated using the method of Schoch et al and dissolved in $20 \mu \mathrm{l}$ of sterile water. ${ }^{3}$ A smear from a normal control was processed similarly.

A $5 \mu \mathrm{l}$ aliquot of DNA was subjected to PCR to amplify the promoter, exon 1, IVS-1, and exon 2 of the $\beta$ globin gene (forward primer, B-1-F: 5'-ATATTCTGGAGACGCAGGAAGA GATCC-3' and reverse primer, B-109-R: 5'-CCCTTCCTATGA CATGAACTTAACCAT-3'). Denaturation of $0.25 \mu \mathrm{g}$ of genomic DNA in $45 \mu \mathrm{l}$ of $1 \times$ buffer was carried out at $97^{\circ} \mathrm{C}$ for five minutes, followed by five minutes at $85^{\circ} \mathrm{C}$, during which 1.25 U Taq DNA polymerase (Perkin Elmer, Brunchburg, New Jersey, USA) was added. The PCR consisted of 30 cycles of denaturation for one minute at $94^{\circ} \mathrm{C}$, annealing for one minute at $58^{\circ} \mathrm{C}$, and elongation for two minutes at $72^{\circ} \mathrm{C}$, with a final elongation step of 10 minutes at $72^{\circ} \mathrm{C}$ after the last cycle. The PCR product was analysed on a $1 \%$ agarose gel, stained with ethidium bromide, and photographed on Polaroid film. The PCR product was purified using the BioRad gene prep-A purification kit (Bio-Rad Laboratories Inc, Hercules, California, USA). A $10 \mu$ aliquot was submitted to the molecular biology core facility at MCG for cycle sequencing with the Big Dye Terminator (BDT) method on an ABI PRISM ${ }^{\mathrm{TM}} 377$ sequencer (Applied BioSystems Inc, Foster City, California, USA). The nucleotide sequences of the $\beta$ globin gene from the patient and a normal control were screened with the reference sequence (HUMHBB) using the GenBank (BLAST) program.

\section{RESULTS}

Sequencing of the $\beta$ globin gene from the patient revealed an $\mathrm{A} \rightarrow \mathrm{G}$ mutation at nucleotide -29 in the TATA box of the promoter and an $A \rightarrow G$ mutation at codon 6 in exon 1 $(\mathrm{GAG} \rightarrow \mathrm{GTG}$; Glu $\rightarrow$ Val) (fig 1), establishing a postmortem diagnosis of $S-\beta^{+}$thalassaemia. No mutations were found in the normal control.

The complete sequence of the $\beta$ globin gene was submitted to GenBank (accession number AY356351).

\section{DISCUSSION}

$S-\beta^{+}$thalassaemia is a heterogeneous disorder ranging from severe SCD in Mediterranean populations to a mild phenotype in blacks. The clinical severity is determined by the $\beta^{+}$thalassaemia mutation; mutations that significantly reduce the output of the affected globin gene result in lower amounts of haemoglobin A $(<10 \%)$ in red blood cells and lead to a more severe sickling disorder. Mutations that cause a moderate reduction in the output of the $\beta$ globin gene do not result in such low concentrations of haemoglobin $\mathrm{A}$

Abbreviations: MCG, Medical College of Georgia; PCR, polymerase chain reaction; SCD, sickle cell disease 


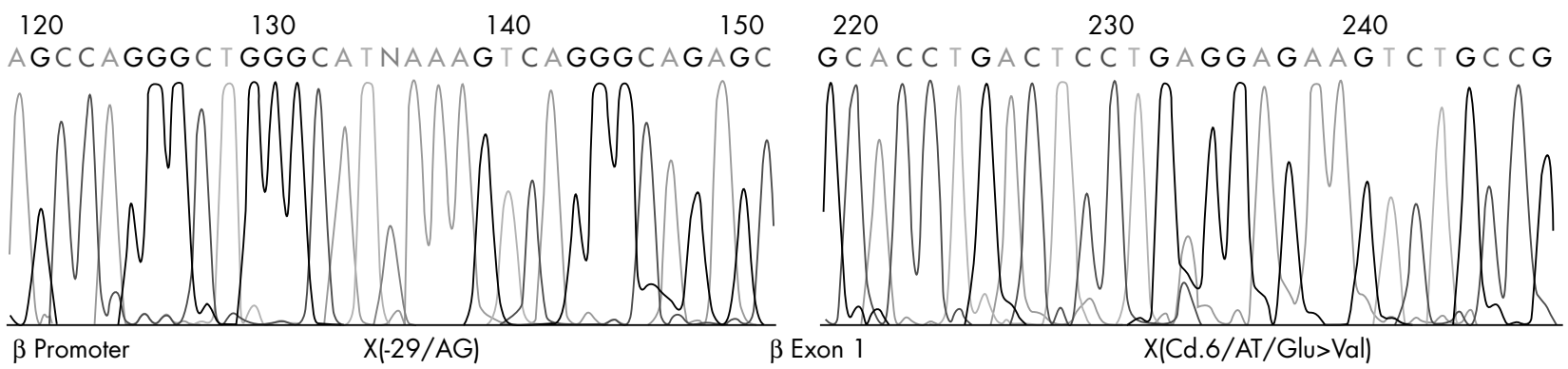

Figure 1 Detection of the $\beta$ globin gene promoter region mutation $-29 A \rightarrow G$, shown at the left of the electropherogram, and the codon $6 \mathrm{~A} \rightarrow T$ (Glu $\rightarrow$ Val) mutation, shown at the right of the electropherogram, by sequencing of polymerase chain reaction amplified DNA.

\section{Take home messages}

- We report a 68 year old black patient who was diagnosed with sickle cell disease at necropsy, although the disease had not been diagnosed during her lifetime

- DNA was isolated from a peripheral blood smear obtained on the day of the patient's death and molecular analysis of the $\beta$ globin gene confirmed that this patient had S- $\beta^{+}$thalassaemia

- Our study shows that relatively "mild" forms of sickle cell disease can be overlooked despite symptomatology suggestive of a sickle syndrome, and demonstrates the feasibility of the postmortem molecular diagnosis of haemoglobinopathies in such cases

(15-20\% of normal) and are clinically milder. ${ }^{6}$ The common $\beta^{+}$thalassaemia mutations in blacks $(-29 \mathrm{~A} \rightarrow \mathrm{G}$ and -88 $\mathrm{C} \rightarrow \mathrm{T}$ ) belong to this last group. ${ }^{7}$ Although generally considered mild, S- $\beta^{+}$thalassaemia in blacks can result in severe complications of SCD. Our patient's terminal event started with chest, arm, and back pain, as a result of a sickle cell vaso-occlusive crisis that evolved into an acute chest syndrome and multiorgan failure. Unfortunately, a diagnosis of SCD was not established during the patient's lifetime, presumably because of her "mild" course. Detailed information on this patient's past medical and social history and medical management were not available to the authors because she was not followed in the sickle cell center at MCG.

"It is important to entertain undiagnosed sickle cell syndrome in the differential diagnosis of respiratory failure and multiorgan failure in populations at risk for haemoglobinopathies"

This case illustrates that so called "mild" cases of SCD can go undiagnosed until later in life. Although this patient's history (cholecystectomy because of gallstones and a total hip replacement secondary to osteonecrosis of the femoral head) is suggestive of SCD, the lack of features of "typical" severe SCD (frequent pain crises and severe anaemia), and the failure to consider SCD in the differential diagnosis, allowed this patient's condition to go undiagnosed. It is important to entertain undiagnosed sickle cell syndrome in the differential diagnosis of respiratory failure and multiorgan failure in populations at risk for haemoglobinopathies, particularly in the absence of other aetiological factors. DNA sequencing can be an important supplement to postmortem examinations in cases like these to establish a definitive diagnosis.

\section{Authors' affiliations}

F Kutlar, L Holley, A Kutlar, Department of Medicine, Sickle Cell Center, Medical College of Georgia, Augusta Georgia, GA 30912, USA

D Mirmow, Aiken Regional Medical Center, Pathology Department, Aiken, South Carolina, USA

M Glendenning, Department of Biochemistry and Molecular Biology, Medical College of Georgia

Correspondence to: Professor F Kutlar, DNA Laboratory of the Titus $\mathrm{H}$. J. Huisman Hemoglobinopathy Laboratory, Sickle Cell Center, Medical College of Georgia, 1120 15th Street, AC-1004, Augusta, GA 30912, USA

Accepted for publication 1 July 2004

\section{REFERENCES}

1 Coleman MB, Steinberg MH, Adams JG 3rd. Hemoglobin Terre Haute arginine beta 106. A posthumous correction to the original structure of hemoglobin Indianapolis. J Biol Chem 1991;266:5798-800.

2 Filon D, Faerman $M$, Smith $P$, et al. Sequence analysis reveals a betathalassaemia mutation in the DNA of skeletal remains from the archaeological site of Akhziv, Israel. Nat Genet 1995;9:365-8.

3 Schoch RM, Jenisch S, Haferlach T, et al. Glass slide smears are a suitable source for RT-PCR based analysis of chromosomal aberrations in leukaemias. Br J Haematol 1996;40:142.

4 Yokota M, Tatsumi N, Tsuda I, et al. DNA extraction and amplification from Giemsa-stained blood smears. J Clin Lab Anal 1995;9:387-91.

5 de Melo MB, Sales TS, Lorand-Metze I, et al. Rapid method for isolation of DNA from glass slide smears for PCR. Acta Haematol 1992;87:214-15.

6 Weatherall DJ, Clegg JB. The thalassaemia syndromes, 4th ed. Oxford: Blackwell Science, 2001.

7 Gonzalez-Redondo JM, Kutlar A, Kutlar F, et al. Molecular characterization of $\mathrm{Hb} \mathrm{S}(\mathrm{C}) \beta$-thalassemia in American blacks. Am J Hematol 1991;38:9-14. 